\title{
DOŚWIADCZANIE CHOROBY ALKOHOLOWEJ W RODZINIE (W UJĘCIU SOCJOLOGICZNYM)
}

\author{
Abstract \\ Experiencing alcoholism in the family (in sociological terms)
}

In order for a social worker to understand individuals with alcohol use disorders, the physical, emotional, psychological, historical, and social contexts of those individuals must also be examined. One of the most powerful and influential social contexts across a person's lifespan is the family system-including the family of origin and the various family systems and subsystems that operate at any point in time. The family systems and family members may have a role to play in an individual's recovery from alcohol problems, or may interfere with the process. On the other hand, the alcohol problems of one family member may lead to or co-occur with a distortion of family process, thereby increasing the risk of family breakdown, dysfunction, violence, or other problems leading to social work intervention. The article attempts to show and interpret the subjective experiences of a person in whom the biography has been entered into an alcohol disease.

Key words: sociology of social problems, sociology of family, alcoholism, biographical method

\section{Wstęp}

System rodzinny - w tym rodzina pochodzenia oraz różne systemy i podsystemy rodzinne - ma duże znaczenie dla każdej jednostki. Systemy rodzinne i członkowie rodziny mogą odgrywać rolę w odrodzeniu się jednostki z problemu alkoholowego, mogą wpływać na ten proces. Problemy alkoholowe jednego członka rodziny prowadzą do zakłóceń w systemie rodzinnym, zwiększając w ten sposób ryzyko rozpadu rodziny, dysfunkcji, przemocy lub innych trudności wiodących do interwencji w pracy socjalnej.

Fritz Schütze (1997: 27-28) stosuje określenie trajektorii ${ }^{1}$ alkoholicznej. Uważa, że badania nad tą trajektorią, prowadzone w dłuższym czasie, mogą wyjaśnić główne

1 W literaturze naukowej podkreślono: „ukuliśmy termin trajektorii, aby opowiedzieć nie tylko o rozwoju choroby pacjenta, ale o całkowitej organizacji pracy wykonanej nad przebiegiem choroby plus jej wpływ na osoby wykonujące tę pracę i jej organizację. Dla różnych chorób trajektoria będzie obejmowała różne medyczne i opiekuńcze działania, różne rodzaje umiejętności i inne środki, różny podział zadań wśród pracowników (włączając być może krewnych i samego pacjenta), będzie obejmowała 
zagadnienia badawcze w zakresie diagnostyki i terapii uzależnień: $\mathrm{w}$ jakich warunkach samo zachowanie i odpowiadająca mu subkultura należą do pierwotnego układu uwarunkowań trajektorii uzależnienia, a także w jakich warunkach uzależnienie od danej substancji wypływa z biotycznego przekształcenia trajektorii cierpienia o źródłowo innym, najczęściej społecznym charakterze. Analiza umożliwia również poznanie licznych mechanizmów i dynamiki przebiegu uzależnienia, z uwzględnieniem interwencji „znaczących innych”, a także wypracowania strategii zniekształconego postrzegania rzeczywistości. Koncepcja trajektorii koncentruje się na wymiarach pracy biograficznej osoby uzależnionej od alkoholu, co jest przypuszczalnie istotnym czynnikiem w biograficznym przebiegu rehabilitacji jednostki. W artykule podjęto próbę ukazania oraz interpretacji subiektywnych doświadczeń osoby, w której biografię została wpisana choroba alkoholowa ${ }^{2}$.

\section{Specyfika choroby alkoholowej}

Pojęcie alcoholismus chronicum wprowadził w XIX wieku Magnus Huss. W 1960 roku amerykański lekarz Elvin Morton Jellinek (1960) przedstawił, w jaki sposób dochodzi do powstawania i pogłębiania się uzależnienia od alkoholu. Wyróżnił stadia choroby alkoholowej, tak zwane fazy: (1) wstępną prealkoholową, trwającą od kilku miesięcy do kilku lat, zaczynającą się od konwencjonalnego stylu picia. Człowiek odkrywa, że picie alkoholu nie tylko daje przyjemne doznania, lecz także łagodzi przykre stany emocjonalne. Wzrasta tolerancja na alkohol; (2) ostrzegawczą, zaczynającą się w momencie pojawienia się luk pamięciowych (palimpsestów); (3) krytyczną, rozpoczynającą się od utraty kontroli nad piciem; (4) przewlekłą, zaczynającą się wraz z wystąpieniem wielodniowych ciągów.

Szacuje się, że w Polsce liczba dorosłych osób żyjących w otoczeniu alkoholika wynosi $1,5 \mathrm{mln}$. Taka sama jest liczba dzieci wychowujących się w rodzinie osoby uzależnionej od alkoholu. Liczba osób uzależnionych od alkoholu wynosi około 800 tys., natomiast

ona jednocześnie całkowicie różne stosunki - instrumentalne i ekspresyjne” (Strauss, Fagerhaugh, Suczek, Wiener 1985: 8).

2 Głównym celem przeprowadzonego badania było poszukiwanie odpowiedzi na pytania o indywidualny sens doświadczeń, o relacje z innymi oraz zmianę zachowań ukierunkowanych na podejmowanie działań życiowych. Poszukiwano odpowiedzi na pytanie badawcze: jakie znaczenie nadaje respondent treści swoich doświadczeń? Badanie zostało przeprowadzone w sierpniu 2018 roku przez autorkę artykułu, z zastosowaniem metody biograficznej, techniki wywiadu narracyjnego. Metoda indywidualnych przypadków to pewien sposób badań, „polegający na analizie jednostkowych losów ludzkich uwikłanych w określone sytuacje wychowawcze lub na analizie konkretnych zjawisk natury wychowawczej poprzez pryzmat jednostkowych biografii ludzkich z nastawieniem na opracowanie diagnozy przypadku lub zjawiska w celu podjęcia działań terapeutycznych" (Pilch, Bauman 2001: 48). Na temat analizy pojedynczych przypadków piszą m.in. D. Bertaux (2012: 309-333; Szluz 2016: 362-370). Płeć i wiek respondenta - kobieta, 49 lat. Ze względu na ochronę danych osobowych nie podano miejsca przeprowadzenia wywiadu, usunięto nazwy miejscowości i inne nazwy własne. 
od 2 do 2,5 mln osób pije alkohol szkodliwie. Ofiarami przemocy w rodzinach z problemem alkoholowym jest około 2 mln osób dorosłych i dzieci (PARPA 2018).

Badania wskazują, że czynniki genetyczne mogą przyczyniać się do rozwoju alkoholizmu. Rodzinne badania rodowodów zwykle wykazują wzrost częstości występowania uzależnienia w ciągu życia wśród biologicznych krewnych. Wzrost ryzyka dla krewnych pierwszego stopnia (brat/siostra i rodzic/dziecko) jest od czterech do siedmiu razy większy niż ryzyko w populacji ogólnej (Merikangas 1990: 11-22). Osoby wychowane w rodzinach, w których nadużywany jest alkohol, są zagrożone rozwojem problemów alkoholowych zarówno z powodu czynników genetycznych, jak i wadliwego modelowania roli (O’Farrell 1995: 195-220). Dla rodzin osób z zaburzeniami używania alkoholu charakterystyczne są: konflikty, chaos, problemy z komunikacją, nieprzewidywalność, niespójność przekazów do dzieci, rozpad rytuałów i tradycyjnych zasad rodzinnych, przemoc emocjonalna i fizyczna (Connors, Donovan, DiClemente 2001).

„Znaczący inny” może wspierać proces zmian, ale konieczne może być zajęcie się: (1) jego trudnościami wynikającymi z próby radzenia sobie z problemami alkoholowymi partnera oraz (2) jego ambiwalencją w zakresie zmiany zachowań, które z kolei wiążą się z modyfikowaniem zachowań jednostki związanych z piciem, a także (3) sposobami rozwijania konsensusu między partnerami na temat celów leczenia (Burke, Vassilev, Kantchelov, Zweben 2002: 347-361). Zaangażowanie „znaczącej innej” osoby może przynieść skutek przeciwny do zamierzonego, jeśli ta osoba jest przytłoczona, nadmiernie rozgniewana i urażona i/lub niezaangażowana w zmiany (Longabaugh, Beattie, Noel, Stout, Malloy 1993: 465-478). Edukowanie znaczącego innego może być szczególnie ważne w sytuacjach, w których alkoholik nie zastanawia się nad zmianą, a dana osoba może pomóc $\mathrm{w}$ podjęciu leczenia przez uzależnionego.

\section{Analiza przebiegu trajektorii}

Beata Tobiasz-Adamczyk (2009: 116) zauważyła, że obiektywna trajektoria choroby może w zróżnicowany, odmienny sposób wpływać na postrzeganie choroby przez jednostkę oraz na jej sytuację społeczną. Badacze (Riemann, Schütze 2012: 389) starali się zrozumieć i analizować to, jak choroba w ogóle, choroba przewlekła, ból i umieranie są postrzegane oraz w jaki sposób odnoszą się do nich pacjenci, ich rodziny oraz personel medyczny. A.L. Strauss, S. Fagerhaugh, B. Suczek, C. Wiener podkreślili, że:

prowadzenie trajektorii choroby przypomina pracę pilota parowca na rzece Missisipi opisaną przez Marka Twaina: rzeka jest niebezpieczna, każdego dnia nieco zmienia swój bieg, tak że nawet doświadczony, choć nieuważny, pilot może wpaść w śmiertelne tarapaty; co gorsza czasami na odcinku kilkunastu kilometrów rzeka zmienia koryto, mając całkiem inny nurt. (...) prowadzenie, kształtowanie i doświadczanie - tworzą zdecydowanie adekwatny obraz tego, co się dzieje, gdy trajektorie są złożone i problematyczne" (Strauss, Fagerhaugh, Suczek, Wiener 2012: 375-376). 
Mając na uwadze uwarunkowania, przebieg i rokowania w przypadku choroby alkoholowej, tę trajektorię można uznać za złożoną i wieloproblemową.

Ian Robinson (1990: 1173-1186) wyróżnia trzy trajektorie: biologiczno-medyczną, wynikającą obiektywnie z choroby, trajektorię związaną z subiektywnym odczuciem choroby oraz społeczną, wyznaczoną sytuacją społeczną wiążącą się z legalizacją społeczną wspomnianej choroby. Pierwsza $\mathrm{z}$ wymienionych trajektorii ma swój początek jeszcze w okresie bezobjawowym. W momencie, w którym jednostka zauważa objawy choroby, dochodzi do jej ujawnienia się. Zmienia się status osoby z jednostki zdrowej na chorą.

Moje dzieciństwo było trudne, ponieważ ojciec pił. Z relacji mamy wiem, że pił jeszcze przed ślubem, wtedy kiedy była ze mną w ciąży, i potem w kolejnych latach naszego życia. Pracował w państwowym zakładzie pracy. Potem założył mały zakład prywatny, ciężko pracował, ale nadal pił. Miewał okresy, krótsze lub dłuższe, podczas których nie pił. Życie naszej rodziny naznaczone było wieloletnim piciem alkoholu przez ojca.

Przebieg choroby jest uzależniony od jej natury, momentu zgłoszenia się do lekarza, od wyzwań i możliwości interwencji medycznej. Ważnym momentem jest zdiagnozowanie choroby u jednostki. Diagnoza określa początek pracy nad trajektorią. Po dokonaniu rozpoznania lekarz uzyskuje schemat trajektorii, czyli wyobrażenie sekwencji potencjalnych zdarzeń i przewidywanych działań (Strauss, Fagerhaugh, Suczek, Wiener 2012:373-374). W przypadku choroby alkoholowej tylko część osób podejmuje dobrowolne leczenie (ma motywację do podjęcia terapii). Jednostka może być także poddawana leczeniu, do którego została zobowiązana przez sąd (na mocy decyzji sądu jest odprowadzana do placówki terapeutycznej). Postępowanie zostaje wszczęte, kiedy zaistnieją dwie przesłanki: (1) alkoholik trwa w nałogu bardzo długo i nie chce z własnej woli poddać się leczeniu; (2) przesłanki społeczne - alkoholik swoim zachowaniem stwarza zagrożenie dla zdrowia i życia innych, np. jest sprawcą przemocy w rodzinie, utrudnia wychowanie dzieci. W wielu rodzinach choroba alkoholowa jest ukrywana, a nawet zaprzecza się jej występowaniu. Osoba uzależniona od alkoholu oraz osoby współuzależnione nie są poddawane terapii. Rodzina doświadcza zatem choroby, która trwa wiele lat, pogłębia się, przechodzi przez kolejne fazy prowadzące do śmierci, także z powodu chorób towarzyszących uzależnieniu od alkoholu. Choroba alkoholowa jest schorzeniem, w którego przebiegu rodzina - nie lecząc chorego, nie podejmując działań w tym kierunku - doprowadza członka rodziny do śmierci (nawet w przebiegu np. chorób wenerycznych, AIDS rodzina podejmuje działania ukierunkowane na leczenie jednostki).

Mama pracowała jako nauczycielka. Ona ciągle ukrywała problem alkoholowy ojca. Chodziła i szukała go. Wciągała mnie w te poszukiwania. Mówiła, że jej nie wypada, bo jest nauczycielką, a ja musiałam iść i go wyciągać z jakiegoś miejsca, pijanego i w okropnym stanie. On ciągle coś gubił, np. nowy rower, skórzaną kurtkę itd. Mnie mama wysyłała na poszukiwania. To był jakiś koszmar. Jako starsze spośród dwojga dzieci w rodzinie szybko musiałam dorosnąć. Robiłam zakupy, pilnowałam brata, sprzątałam, załatwiałam wiele spraw urzędowych, które powinni jednak rozwiązywać rodzice. 
Moje życie było przepełnione strachem, lękiem o to, czy znowu ojciec wróci pijany. Im byłam starsza, tym bardziej się wstydziłam. Wszyscy dookoła wiedzieli, że ojciec pije, ale nikt nic nie robił. Mama tylko ciągle krzyczała, a babcia z nim rozmawiała o problemie. Ojciec nie był agresywny, ale podczas upojenia chciał gdzieś iść, uciekać i gdzieś jechać. Nie mieliśmy samochodu, ponieważ po jednej z libacji z kolegami ojciec znalazł się w izbie wytrzeźwień, po wypadku spowodowanym autem kolegi. Policja przyjechała do naszego domu i zabrała mu prawo jazdy, którego już nigdy nie odzyskał. On stwarzał zagrożenie dla nas. Wiózł brata na bagażniku, będąc pijanym, i uszkodził mu stopę, która małemu dziecku wpadła w koło. Upijał się, kiedy zostawał w domu, opiekując się bratem. Zasypiał upojony alkoholem. Nasze życie przepełniał strach, niepokój i ogromny wstyd. Byliśmy jako dzieci zdyscyplinowani, solidni, bardzo dobrze uczyliśmy się w szkole. Ja byłam pilna, perfekcyjna. Brat miał większą swobodę. Mama ciągle narzekała, na wszystko i wszystkich. Niczego nie zrobiła, żeby przerwać ten rodzinny dramat. Był tylko jeden moment, kiedy planowała, że wyprowadzi się z nami do dziadków, ale nigdy tego nie zrobiła. Nikt z rodziny, mimo że wszyscy wiedzieli o problemie, nic nie zrobił. Ojciec przecież zawsze w towarzystwie się upijał. Tkwiliśmy w tym zakłamaniu, wstydzie, koszmarze całe nasze dzieciństwo i naszą młodość.

Radzenie sobie w sytuacjach trudnych jest odmienne dla poszczególnych jednostek. Współuzależniona żona nie podejmowała żadnych działań mających na celu przezwyciężenie problemu alkoholowego męża. U dzieci rozwijało się współuzależnienie (córka została zdiagnozowana jako dorosły potomek alkoholika i odbyła terapię, natomiast syn uzależnił się od alkoholu).

Trajektoria związana z obiektywnym przebiegiem choroby może zmierzać do wyzdrowienia, oznaczać stabilizację choroby lub prowadzić do dalszego jej rozwoju, a nawet śmierci (Robinson 1990: 1173-1186; szerzej Ostrowska 1991; 2005). W przypadku problemów z alkoholem przechodzenie przez poszczególne fazy (stadia uzależnienia) nakreśla możliwości wiążące się z zaprzestaniem picia (pogłębianie się uzależnienia w kolejnych fazach).

Po moim wyjściu za mąż zamieszkał w naszym domu mój mąż. Wtedy ojciec ostatni raz się upił, chciał znowu gdzieś iść, ale mąż przytrzymał ojca i to był ostatni moment jego picia. Nagle po wielu latach przestał pić. Rozmowy mamy, nowa osoba w domu, nowa sytuacja spowodowały, że zakończył picie. Potem już nigdy się nie upił.

W przebiegu choroby pojawiła się niepewność związana z jej przebiegiem. Punkt zwrotny nastąpił w momencie, w którym mężczyzna postanowił uporać się z problemem (transformacja tożsamości). Tożsamość podlega transformacjom podczas wspomnianych punktów zwrotnych, czyli przypadków krytycznych, które zmuszają jednostkę do refleksji wskazującej, iż nie jest już ona tym, kim była w przeszłości (Strauss 1969: 93; 1993: 44-45). Plany działania osoby zmieniają się, prowadzi to do kształtowania nowego wizerunku siebie, nowej tożsamości. Po zamknięciu okresu picia alkoholu mężczyzna uzyskał potwierdzenie, że jego życie będzie biegło dalej, a jego jakość się zmieni. Został jednak wprowadzony w świat społeczny rodziców, których dzieci są alkoholikami. 
Można powiedzieć, że historia zatoczyła koło. Nasza rodzina to cztery osoby: ja - dorosły potomek alkoholika, niepijący, mama - współuzależniona i ojciec, który wiele lat pił, a potem nagle przestał pić, no i brat alkoholik. Nikt się nami nie zainteresował, żadne służby, po prostu tkwiliśmy sami w tym wszystkim. Dramat czwórki ludzi, nierozwiązany dramat, który naznaczył życie rodziny, jednej rodziny wśród wielu, które mają takie bardzo trudne życiowe doświadczenia. Pamiętam, że pewnego razu upił się mój brat. Mama płakała, mówiła, że tak bardzo go kochała, a on jej to zrobił. Wyprowadziliśmy się do własnego mieszkania. Po pewnym czasie okazało się, że brat zaginął. Rodzice nie wiedzieli, gdzie jest. Ja chciałam dzwonić na policję, ale oni nie chcieli. Rozpytywali wśród kolegów, czekali, aż wróci. Uszanowałam ich decyzję, ale nie mogłam jej zrozumieć. Nie wyjaśnili, kiedy już się znalazł, co się stało i gdzie on był. Po kilku latach brat się ożenił i zamieszkał u teściów. Potem zauważyliśmy, całkiem przypadkowo, że mieszka u rodziców. Trwało to półtora miesiąca. Wrócił do żony. Po chyba roku miał operację i znowu zamieszkał u rodziców. To nas zaniepokoiło. Jesienią okazało się, że żona złożyła pozew o rozwód. Umówiłam się z nią na rozmowę, bo w zasadzie oprócz luźnych spotkań świątecznych nie miałyśmy kontaktu. Nie wiem w zasadzie dlaczego, ale nasze zaproszenia nie były przyjmowane. Bez wyjaśnienia. Doznałam szoku, kiedy bratowa powiedziała, że mój brat jest alkoholikiem. Nie mogłam uwierzyć, bo rodzice nic nie wspominali, nikt nic nie mówił. Ona chciała go leczyć, prosiła ich o wsparcie, ale go nie uzyskała i poddała się. Powiedziała, że go kocha, ale chce normalnie żyć i że się go po prostu boi. Usłyszałam wtedy, że rodzice nie pomogą, tylko ja teraz zostaję. Przeszliśmy z moim mężem razem z nim ten rozwód. Podjęliśmy próbę leczenia ambulatoryjnego. Nie udało się. Przyczyna tkwiła m.in. w tym, że mama ciągle wprowadzała w nasze życie konflikt, który trwał między rodzeństwem. Wprowadzała ciągle rywalizację. Mimo moich i męża działań nad wsparciem, zgodą i równowagą, mama ciągle wprowadzała zamieszanie. Rodzice nie wspierali nas w działaniach. Tkwili w świecie zakłamania, iluzji, depresji, beznadziejności. Nie rozumieli choroby alkoholowej. Brat pił coraz bardziej, zabierała go karetka z ulicy. Przebywał z alkoholikami, okradano go. Nie pracował. Był na rencie, ponieważ miał chorą nogę i kręgosłup. Ojciec prowadził tę małą firmę, którą przekazał bratu. W zasadzie zarabiał na alkohol syna. Uciekał, mimo swoich chorób, w pracę, od mamy, brata, albo spał w dzień. Ciągle próbowaliśmy leczyć brata, ale rodzice nas nie wspierali. Mama go szukała, wysyłała ojca, aby go szukał. Biła go po twarzy, krzyczała. Ojciec krzyczał i groził, że go z domu wyrzuci. Brat pije i jest coraz gorzej. Teraz pije już codziennie, załatwia się do łóżka, nie myje, krzyczy, jest agresywny i nieobliczalny. Rodzice poszli do GOPS-u i zgłosili go na przymusowe leczenie do komisji rozwiązywania problemów alkoholowych.

Kathy Charmaz (1997: 30-33, 42-66, 73-85; Skrzypek 2011: 214-221) zbudowała trójelementową kategoryzację sposobów doświadczania choroby przewlekłej. Jej rozpoznanie wiąże się z „przerwaniem ciągłości życia”. „Załamaniu” ulega dotychczas prowadzone życie. „Wkracza” w nie choroba. W życie rodziny ponownie wdarło się uzależnienie, wnosząc cierpienie. „Przerwanie ciągłości życia” jest nacechowane postrzeganiem choroby w kategoriach oczekiwania na powrót do zdrowia, zostaje zanegowane, ponieważ chory nie chce poddać się leczeniu. „Znaczący inni” także nie podejmowali próby leczenia, tylko respondentka wraz z mężem rozpoczęli działania ukierunkowane na przystąpienie do terapii, które bez wsparcia rodziców i motywacji chorego okazały się bezskuteczne. Widoczne i utrwalone konsekwencje powodują, że 
choroba jest „wydarzeniem natrętnym”. „Zakotwicza się" w codziennym życiu, powodując jego zakłócenie. Choroba staje się integralnym elementem osobistej tożsamości chorego. Dostrzegane jest „pogrążanie się w chorobie”. Relacje społeczne chorego słabną, widoczne jest „kurczenie się światów społecznych” jednostki. Zakres aktywności chorego zmienia się, wypracowuje on strategie funkcjonowania na co dzień. Następuje „zatapianie się w chorobie” (kim jestem?, kim będę?) oraz „redefiniowanie choroby” w aspekcie czasu na refleksję i oceny własnego życia osoby (widoczne w przypadku ojca).

W przypadku chorób przewlekłych, zdaniem K. Charmaz (1983: 168-195), chory weryfikuje dotychczasowe doświadczenia życiowe, społeczne oraz kulturowe, wiedzę na temat choroby i przypisywanego jej znaczenia. Jednostka próbuje poznać zmiany w tożsamości społecznej, które są następstwem choroby (miało to miejsce w przypadku ojca, ale nie nastąpiło dotąd w przypadku syna).

Doświadczanie choroby jest to proces psychospołeczny. K. Charmaz (1997: 38) podkreśliła znaczenie „społecznej widowni” w definiowaniu choroby, a także jej monitorowaniu. Zauważalna jest „widownia prywatna” (aktorzy i widzowie ze sceny przewlekłego doświadczania choroby alkoholowej), posiadająca wiedzę na temat choroby i sytuacji osoby chorej, $i$,widownia publiczna” mająca tylko fragmentaryczne informacje. Choroba alkoholowa była przez rodzinę ukrywana. Przewlekłość każdej choroby, a szczególnie związanej z uzależnieniem od alkoholu, jest związana z modyfikowaniem nastawienia od zrozumienia do potępienia.

Współuzależniona kobieta nie chciała otwierać przestrzeni dla plotek. Podzieliła ludzi na tych, z którymi mogła porozmawiać (najpierw była to córka, pełniąca rolę „bohatera rodzinnego", potem mąż), oraz tych, w odniesieniu do których zakładała całkowite milczenie (niemówienie o chorobie alkoholowej jest udawaniem normalności). Współuzależnienie jest postrzegane jako zespół cech, zachowań będących reakcjami na picie osoby bliskiej, mające charakter nieprzystosowawczy (Chodkiewicz 2006: 105-112). Wsparcie społeczne nie zostało uruchomione. W prowadzeniu czy kształtowaniu trajektorii uczestniczyła rodzina (łuk pracy, to znaczy całość pracy do wykonania ${ }^{3}$ ). Inne osoby zaczynają w niej uczestniczyć dopiero w momencie złożenia wniosku o objęcie leczeniem uzależnionego od alkoholu syna.

\section{Podsumowanie}

Część sytuacji kryzysowych można przewidzieć, lecz niewiele z nich można kontrolować. W przeprowadzonych analizach dostrzeżono trajektorię biologiczno-medyczną, która wynikała obiektywnie z choroby, oraz tę związaną z subiektywnym odczuciem choroby, a także trajektorię społeczną. Trajektoria choroby wpłynęła na jej postrzeganie przez jednostki i na sytuację społeczną rodziny. Mając na uwadze wspomnianą trajektorię

3 Na temat faz trajektorii, łuku pracy i sekwencji zadań szerzej piszą A.L. Strauss, S. Fagerhaugh, B. Suczek, C. Wiener (2012: 385-388). 
społeczną, która jest wyznaczona sytuacją społeczną wiążącą się z legalizacją społeczną, należy podkreślić, że szczególne znaczenie mają „znaczący inni”, którzy pojawiają się dopiero po wielu latach. Rodzina była narażona na ryzyko w każdej minifazie trajektorii choroby (trajektoria ryzykowna), także np. na ryzyko ponownego wystąpienia choroby alkoholowej i współuzależnienia.

\section{Bibliografia}

Bertaux D. (2012). Analiza pojedynczych przypadków (au cas par cas), w: K. Kaźmierska (red.), Metoda biograficzna w socjologii. Wydawnictwo Nomos, Kraków: 741-760.

Burke B.L., Vassilev G., Kantchelov A., Zweben, A. (2002). Motivational interviewing with couples, w: W.R. Miller, S. Rollnick (red.), Motivational Interviewing: Preparing People for Change. Guilford, New York: 347-361.

Charmaz K. (1983). Loss of self. A fundamental form of suffering in the chronically ill. „Sociology of Heath and Illness", 5: 168-195.

Charmaz K. (1997). Good Days, Bad Days. The Self in Chronic Illness and Time. Rutgers University Press, New Brunswick, New Jersey.

Chodkiewicz J. (2006). Zapobieganie nawrotom w chorobie alkoholowej-przeglad piśmiennictwa. „Psychiatria”, 3: 105-112.

Connors G.J., Donovan D.M., DiClemente C.C. (2001). Substance Abuse Treatment and the Stages of Change: Selecting and Planning Interventions. Guilford Press, New York.

Jellinek E.M. (1960). The Disease Concept of Alcoholism. Hillhouse, New Haven.

Longabaugh R., Beattie M., Noel N., Stout R., Malloy P. (1993). The effect of social investment on treatment outcome. „Journal of Studies on Alcohol”, 54: 465-478.

Merikangas K.R. (1990). The genetic epidemiology of alcoholism. „Psychological Medicine”, 20: 11-22.

O'Farrell T.J. (1995). Marital and Family Therapy, w: R.K. Hester, W.R. Miller (red.), Handbook of Alcoholism Treatment Approaches: Effective Approaches. Allyn and Bacon, Boston: 195-220.

Ostrowska A. (1991). Śmierć i umieranie. Wydawnictwo Alma-Press, Warszawa.

Ostrowska A. (2005). Śmierć $w$ doświadczeniu jednostki i społeczeństwa. Wydawnictwo IFiS PAN, Warszawa.

PARPA (2018). Statystyki; http://www.parpa.pl/index.php/33-analizy-badania-raporty/132-statystyki (dostęp: 25.11.2018).

Pilch T., Bauman T. (2001). Zasady badań pedagogicznych. Strategie ilościowe i jakościowe. Wydawnictwo Akademickie Żak, Warszawa.

Riemann G., Schütze F. (2012). „Trajektoria” jako podstawowa koncepcja teoretyczna w analizach cierpienia i bezładnych procesów społecznych, w: K. Kaźmierska (red.), Metoda biograficzna w socjologii. Antologia tekstów. Wydawnictwo Nomos, Kraków: 389-414.

Robinson I. (1990). Personal narratives, social careers and medical courses. Analysing life trajectories in autobiographies of people with multiple sclerosis. „Social Science and Medicine”, 30: 1173-1186. 
Schütze F. (1997). Trajektoria cierpienia jako przedmiot badań socjologii interpretatywnej. „Studia Socjologiczne”, 1 (144): 11-56.

Skrzypek M. (2011). Perspektywa chorego w socjologii choroby przewlekłej. Wydawnictwo KUL, Lublin.

Strauss A. (1969). Mirrors and Masks. The Search for Identity. The Sociology Press, San Francisco.

Strauss A. (1993). Continual Permutation of Action. Aldine the Gruyter, New York.

Strauss A.L., Fagerhaugh S., Suczek B., Wiener C. (1985). Social Organization of Medical Work. The University of Chicago Press, Chicago.

Strauss A.L., Fagerhaugh S., Suczek B., Wiener C. (2012). Trajektorie choroby, w: K. Kaźmierska (red.), Metoda biograficzna w socjologii. Antologia tekstów. Wydawnictwo Nomos, Kraków: 373-388.

Szluz B. (2016). Дитина з ускладненою інвалідністю в сім'ї. Дослідження випадку, „Вісник Львівського Університету. Серія Педагогічна", 31: 362-370.

Tobiasz-Adamczyk B. (2009). Jakość życia uwarunkowana stanem zdrowia. Nowe spojrzenie na chorego, w: A. Ostrowska (red.), Socjologia medycyny. Wydawnictwo IFiS PAN, Warszawa: 113-144. 